\title{
Cross-sectional dietary deficiencies among a prison population in Papua New Guinea
}

\author{
Camilla Gould', Benoit Tousignant ${ }^{2,3}$, Garry Brian²,4, Robert McKay ${ }^{2,3}$, Rosalind Gibson ${ }^{1}$, Karl Bailey ${ }^{1}$ \\ and Bernard J Venn ${ }^{1 *}$
}

\begin{abstract}
Background: To investigate the dietary adequacy of prisoners of Beon Prison, Madang, Papua New Guinea in response to a report of possible nutritional deficiency.

Methods: We undertook an observational, cross-sectional study. All 254 male inmates (May 2010) were eligible to answer a validated interview-based questionnaire; to have a comprehensive dietary assessment; and to provide blood for biochemical analysis (a-tocopherol, $\beta$-carotene, lutein, thiamin, riboflavin, niacin, folate, homocysteine, zinc, ferritin, and vitamins $A_{1} B_{12}$ and C). Prison guards were invited to participate as a comparison group.

Results: 148 male prisoners (58.3\%) and 13 male prison guards participated. Prison rations consisted of white rice fortified with thiamin, niacin, and iron, tinned tuna, tinned corned beef, water crackers, and black tea, with occasional intakes of fruit and vegetables. Some prisoners received supplementary food from weekend visitors. From assessment of the prisoners dietary data, median intakes of calcium (137 mg), potassium (677 mg), magnesium (182 mg), riboflavin (0.308 mg), vitamin A (54.1 $\mu \mathrm{g})$, vitamin E (1.68 mg), vitamin C (5.7 mg) and folate $(76.4 \mu \mathrm{g})$ were found to be below estimated average requirements (EAR).

Following are the prisoners median $\left(\mathrm{P}_{25}, \mathrm{P}_{75}\right)$ concentration of circulating nutrients and the percentage of prisoners with levels below normal reference ranges or recognized cut-off values: serum retinol $0.73(0.40,1.21) \mu \mathrm{mol} / \mathrm{L}, 46 \%$ below $0.7 \mu \mathrm{mol} / \mathrm{L}$; plasma folate $2.0(1.4,2.6) \mathrm{nmol} / \mathrm{L}$, 98\% below $6.8 \mathrm{nmol} / \mathrm{L}$; plasma vitamin C $6.3(1.0,19.3) \mu \mathrm{mol} / \mathrm{L}$, 64\% below $11.4 \mu \mathrm{mol} / \mathrm{L}$; serum zinc $9.9(8.8,11.1) \mu \mathrm{mol} / \mathrm{L}, 66 \%$ below $10.7 \mu \mathrm{mol} / \mathrm{L}$. Guards had diets with a higher dietary diversity that were associated with greater intakes of nutrients and biomarker concentrations.

Conclusions: The prisoners diets are likely lacking in several micronutrients and recommendations for dietary change have been made to the prison authorities. Ongoing vigilance is required in prisons to ensure the basic human right of access to a nutritionally adequate diet is being observed.
\end{abstract}

Keywords: Prisoner, Prison, Rations, Diet, Nutrition, Deficiency

\section{Background}

Prisoners incarcerated in developing countries have been shown to be vulnerable to dietary deficiencies. Outbreaks of scurvy [1], vitamin A deficiency disorders [2] and beriberi [3] have been documented in various African prisons. The local ophthalmologist in Madang, Papua New Guinea, became aware of adult prisoners developing vision loss during incarceration at the local correctional facility, Beon Prison. For several of the prisoners this was attributed to

\footnotetext{
* Correspondence: bernard.venn@otago.ac.nz

'Department of Human Nutrition, University of Otago, P.O. Box 56, Dunedin 9054, New Zealand

Full list of author information is available at the end of the article
}

optic neuropathy, a condition that may lead to permanent optic nerve dysfunction and blindness although it is rarely present in the general population [4]. The prisoners presenting to the local eye clinic described a diet with little fruit and vegetables, possibly indicative of an inadequate intake of some nutrients. Indeed, nutritional deficiencies and toxic substances have been associated with optic neuropathy $[5,6]$. In response to the report, and in order to provide evidence-based advice to prison authorities, an ophthalmic and nutritional survey was undertaken to identify the prevalence of optic neuropathy and to investigate potential nutritional and toxic correlates of the disease. As a result of this investigation, optic neuropathy

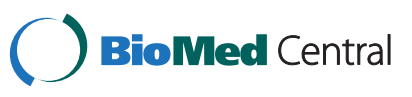


with a prevalence estimate of $10.4 \%$ among prisoners was found to be associated with length of incarceration, age, and low blood folate concentrations [7]. Some prisoners exhibited xerophthalmia associated with vitamin A deficiency [8]. In addition to investigating the prevalence and risk factors associated with optic neuropathy and visual loss, a broader dietary assessment was undertaken to determine whether the inmates of Beon Prison were at risk of other nutrient deficiencies. Here we report on the adequacy of the diets of the prisoners in terms of nutrient intakes and blood biochemistry.

\section{Methods}

In May 2010 there were 254 adult male $(\geq 18 y)$ prisoners at Beon Prison, Madang, Papua New Guinea. Adult male prison guards were also invited to participate in the study as a comparison group. The purpose of the study was explained to all adult prisoners and guards and assurances were given regarding confidentiality of the data. Communications with potential participants were conducted in Papua New Guinean Pidgin (Tok pisin). Care was taken during the investigation to minimize any potential repercussions for participants from both fellow inmates and authorities.

\section{Dietary and lifestyle questionnaire}

An interview-based questionnaire was designed to elicit demographic, socioeconomic, dietary and lifestyle information. Health workers and student health extension officers administered the questionnaire. In addition to dietary intake, questions were asked about smoking and the chewing of betel nut. Dietary intake was assessed using a single interactive 24-hour recall using multiplepass interviewing [9]. Prompts were given based on prison rations and locally available foods brought into the prison by visitors at weekends. Graduated food models, measuring cups, spoons, and prison cups and plates were made available to prisoners and guards to aid with portion estimation. In addition, thirty prison lunches and dinners were weighed over three days using Salter Electronic Kitchen Scales (Model 1035, Salter Housewares Ltd., Kent, UK) accurate to \pm 2 grams. The guards also completed a food frequency questionnaire (FFQ). The nutrient composition of foods were derived primarily from the nutrition information panel or from the Pacific Islands Food Composition Table [10]. For foods not listed in the Pacific Islands dataset, the Australian [11] or the New Zealand [12] food composition tables were used. The nutrient contents of the foods were combined with the intake estimates to yield median (IQR) daily intakes of 26 nutrients. The average energy requirements of prisoners and guards were calculated using individual energy requirements based on body mass and an assumed sedentary physical activity level of 1.4 in accordance with WHO criteria [13].

A fasting venous blood sample was drawn from participants into two evacuated tubes; a trace-element and anticoagulant-free tube, and an EDTA treated vacutainer tube (Becton Dickinson Rutherford, NJ, USA). The tubes were immediately refrigerated and kept in the dark. Within 30 minutes of collection, aliquots of whole blood were taken from the EDTA tubes; the tubes were then centrifuged and aliquots of plasma removed. One plasma aliquot was treated with metaphosphoric acid in preparation for vitamin $\mathrm{C}$ analysis. A sample of the red blood cells were washed and stored for thiamin analysis. One hour after collection, blood in the trace-element free tubes was centrifuged, haematocrit was determined, and serum was aliquoted into trace-element free polyethylene storage tubes. All blood sample preparation was conducted with minimal exposure to light and plasma samples for carotenoid and riboflavin analysis were wrapped in aluminium foil. Samples were stored at $-80^{\circ} \mathrm{C}$, freighted frozen on dry ice to New Zealand, and stored at $-80^{\circ} \mathrm{C}$ until analysed.

Biochemical tests were generally undertaken according to published methods or using manufacturer's kits as follows: serum retinol, $\alpha$-tocopherol, $\beta$-carotene and lutein by high performance liquid chromatography (HPLC) [14]; plasma and whole blood folate by microbiological assay [15]; plasma vitamin $C$ by fluorometric assay [16]; plasma selenium using electrothermal atomic absorption spectrophotometry [17]; plasma total homocysteine (tHCy) by HPLC [18]; and serum zinc using atomic absorption spectrophotometry [19]. Manufacturer's kits were used for serum ferritin, vitamin $B_{12}$, cholesterol and creatinine (Roche Diagnostics GmbH, Mannheim, Germany), serum $\alpha$-1-glycoprotein (Randox Laboratories Ltd, Crumlin, UK), and whole blood riboflavin (Chromsystems Instruments \& Chemicals GmbH, München, Germany). Red blood cell thiamin pyrophosphate was measured by HPLC using an in-house method developed by Canterbury Health Laboratories (Christchurch, New Zealand). Accuracy and precision were monitored and maintained using commercial controls for $\alpha$-tocopherol, $\beta$-carotene, retinol, lutein, selenium, vitamin $B_{12}$, riboflavin, tHcy, cholesterol and creatinine. A reference standard (National Institute ST) was used for folate. Pooled plasma was used to check precision of the thiamin and vitamin $C$ assays.

Differences in the demographic characteristics of prisoners and guards were tested using the Fisher's exact test for categorical variables and the Student's t-test for continuous variables. Differences between nutrient intakes and biomarkers of prisoners and guards were tested using the median test. Analyses were performed using Intercooled Stata 9.2 (Stata Corporation, College Station, TX, USA). Statistical significance was accepted at $P<0.05$. 
Ethics approval was granted both by the institutional ethics review board for the local university (Divine Word University Research Ethics Committee) and by the Medical Research Advisory Committee of Papua New Guinea (MRAC 10.16). All participants gave informed written consent for participation. The tenets of the Helsinki Declaration were observed.

\section{Role of the funding source}

The New Zealand Agency for International Development (NZAID) financially supported the design, implementation and analysis of this study through the Kaihono hei Oranga Hapori o te Ao partnerships for International Community Development scheme (KOHA-PICD), but had no input into or control over content or commentary. The Department of Human Nutrition of the University of Otago provided funding for the design and implementation of the dietary and blood assessment comprising dietary data collection, input and analysis and the on-site processing and laboratory analysis of the blood samples. The Fred Hollows Foundation New Zealand provided funding for the design and implementation of clinical data collection, general study administration, data analysis and write-up.

\section{Results}

Consent and baseline data were obtained from 148 prisoners and 13 guards. The baseline characteristics of the prisoners and guards are presented in Table 1. All study participants were of Melanesian ethnicity. Prisoners had a significantly lower body weight and BMI, and were younger than the guards. According to the WHO (2000) classification, $5 \%$ of the prisoners were underweight $(\mathrm{BMI}<18.5), 81 \%$ had a BMI within the normal range (BMI $\geq 18.5-24.9$ ), and $15 \%$ were overweight (BMI $\geq 25$ 29.9) [20]. Fifty-seven prisoners (39\%) and 4 guards reported weight loss within the previous $3-6$ months. The majority of the prisoners identified themselves as current tobacco smokers despite access to tobacco in the prison being restricted; the number of cigarettes smoked was generally less than 10 per day. Few prisoners reported consuming alcohol in prison, although the majority had been consumers before incarceration.

The prison rations consisted of water-crackers and black tea for breakfast; and white rice topped with tinned corned beef or tuna for the midday and evening meals. There were reports of small amounts of fruit and vegetables being supplied sporadically. Water was available throughout the day. Another source of food for some prisoners was food brought in by weekend visitors. This food had to be eaten in the visiting area and it could not be shared with other prisoners. Most prisoners reported consuming fruit and vegetables rarely or never (66\%), and 91\% reported consumption of these foods less than once per week. In
Table 1 Descriptive characteristics of male prisoners and guards at Beon prison

\begin{tabular}{|c|c|c|c|}
\hline \multirow[t]{2}{*}{ Characteristic } & \multirow{2}{*}{$\begin{array}{c}\begin{array}{c}\text { Prisoners } \\
\mathrm{n}=148^{\mathrm{a}}\end{array} \\
\text { Mean (SD) }\end{array}$} & \multirow{2}{*}{$\begin{array}{c}\begin{array}{c}\text { Guards } \\
\mathrm{n}=13^{\mathrm{a}}\end{array} \\
\text { Mean (SD) }\end{array}$} & \multirow[t]{2}{*}{$P^{b}$} \\
\hline & & & \\
\hline Age (years) & $31.0(7.93)$ & $47.3(10.2)$ & $<0.001$ \\
\hline Height (cm) & $164(6.83)$ & $167(4.27)$ & 0.112 \\
\hline Weight (kg) & $60.6(6.92)$ & $75.8(14.1)$ & $<0.001$ \\
\hline $\mathrm{BMI}\left(\mathrm{kg} / \mathrm{m}^{2}\right)$ & $22.5(2.25)$ & $27.1(5.22)$ & $<0.001$ \\
\hline \multirow{2}{*}{$\begin{array}{l}\text { Time incarceration at Beon } \\
\text { (months) }\end{array}$} & $24.7(27.9)$ & - & \\
\hline & n (\%) & n (\%) & \\
\hline \multicolumn{4}{|l|}{ Smoking status } \\
\hline Current & $103(71)$ & $3(23)$ & $<0.001$ \\
\hline Past & $31(21)$ & $0(0)$ & \\
\hline Never & $12(8.2)$ & $10(77)$ & \\
\hline \multicolumn{4}{|l|}{ Tobacco use } \\
\hline None & $43(29)$ & $9(75)$ & \\
\hline$<1$ cigarette/day & $48(33)$ & $0(0)$ & 0.001 \\
\hline 1-10 cigarettes/day & $46(32)$ & $1(8.3)$ & \\
\hline$\geq 10$ cigarettes/day & $9(6.2)$ & $2(17)$ & \\
\hline \multicolumn{4}{|l|}{ Alcohol status } \\
\hline Current & $19(13)$ & $8(62)$ & $<0.001$ \\
\hline Past & $115(79)$ & $0(0)$ & \\
\hline Never & $12(8.2)$ & $5(38)$ & \\
\hline \multicolumn{4}{|l|}{ Alcohol consumption } \\
\hline None & $128(90)$ & $5(38)$ & \\
\hline$<1$ unit/day & $1(0.7)$ & $0(0)$ & $<0.001$ \\
\hline 1-2 units/day & $2(1.4)$ & $2(15)$ & \\
\hline$\geq 3$ units/day & $12(8.4)$ & $6(46)$ & \\
\hline
\end{tabular}

${ }^{a}$ Not all data are complete.

${ }^{b} P$ value generated from Student's t-test (parametric data) or Fisher's exact test (non-parametric data).

c Unit of alcohol = 1 bottle/can beer, $125 \mathrm{~mL}$ home-made alcohol, 1 glass of wine or $10 \mathrm{~mL}$ spirits.

contrast, most guards reported consuming green vegetables, rice and coconut milk on a daily basis with fruit, fish, meat and nuts consumed 1-3 times/week.

Dietary data based on 24-hr recalls were elicited from 148 prisoners and 9 guards. The mean (SD) portion size of rice estimated by the prisoners was $418 \mathrm{~g}$ (132); this compares well with the mean of $423 \mathrm{~g}$ (62) obtained from weighing 40 rice servings. There was a tendency for the prisoners to underestimate the portion of corned beef and tuna by approximately one-third. The prisoners estimated a topping of corned beef and tuna to be $40 \mathrm{~g}$ (27.1) and $41 \mathrm{~g}$ (19.6), respectively, whereas the weighed amounts were $58 \mathrm{~g}$ (5.7) and $61 \mathrm{~g}$ (5.9).

The nutrient intakes generated from the dietary recalls are presented in Table 2. When compared with the guards, prisoners had significantly lower intakes of fat, saturated 
Table 2 Median daily nutritional intake of male prisoners and guards based on 24-hour dietary recall data and gift recall data

\begin{tabular}{|c|c|c|c|}
\hline & Prisoners $n=148$ & Guards $n=9$ & $P^{1}$ \\
\hline & Median $\left(\mathrm{P}_{25}, \mathrm{P}_{75}\right)$ & Median $\left(\mathrm{P}_{25}, \mathrm{P}_{75}\right)$ & \\
\hline Energy $(\mathrm{k})$ & $7430(6170,8600)$ & $8360(6990,9150)$ & $\mathrm{NA}^{2}$ \\
\hline Protein (g) & $50.5(41.2,59.6)$ & $73.3(46.2,78.2)$ & $\mathrm{NA}^{2}$ \\
\hline Total fat (\% energy) & $13.0(11.6,15.0)$ & $30.1(26.8,42.0)$ & $0.002^{*}$ \\
\hline Saturated fat (\% energy) & $7.15(6.07,8.34)$ & $13.6(10.2,16.9)$ & $0.015^{*}$ \\
\hline Cholesterol (mg) & $45.9(29.9,57.9)$ & $109.0(47.0,158.0)$ & 0.083 \\
\hline Carbohydrates (\% energy) & $76.4(73.7,82.0)$ & $57.7(47.1,62.8)$ & $0.002^{*}$ \\
\hline Total dietary fibre (g) & $9.80(8.08,11.8)$ & $16.9(15.5,17.4)$ & 0.083 \\
\hline Total vitamin A ( $\mu \mathrm{g})$ & $54.1(14.8,104)$ & $666(248,857)$ & $0.014^{*}$ \\
\hline B-carotene equiv $(\mu \mathrm{g})$ & $556(27.6,1100)$ & $6620(1035,7710)$ & 0.069 \\
\hline Retinol $(\mu \mathrm{g})$ & $12.4(7.66,16.6)$ & $129(52,159)$ & 0.083 \\
\hline Thiamin (mg) & $1.09(0.875,1.30)$ & $0.97(0.75,1.10)$ & 0.372 \\
\hline Riboflavin (mg) & $0.308(0.242,0.383)$ & $0.812(0.614,1.09)$ & $0.001^{*}$ \\
\hline Niacin equiv. (mg) & $23.7(19.5,28.2)$ & $22.8(21.5,27.1)$ & 0.746 \\
\hline Vitamin $B_{6}(m g)$ & $1.57(1.02,1.85)$ & $1.58(1.13,1.87)$ & 0.717 \\
\hline Vitamin $B_{12}(\mu \mathrm{g})$ & $2.83(1.49,3.11)$ & $3.06(2.11,4.59)$ & 0.495 \\
\hline Eolate $(\mu \mathrm{g})$ & $76.4(61.3,93.1)$ & $238(108,263)$ & $0.015^{*}$ \\
\hline Vitamin C (mg) & $5.7(1.3,10.2)$ & $85.1(29.5,105.0)$ & $0.012^{*}$ \\
\hline Vitamin E (mg) & $1.68(1.15,2.30)$ & $7.69(4.55,9.84)$ & $0.015^{*}$ \\
\hline Sodium (mg) & $1560(1230,1920)$ & $1710(1350,2340)$ & 0.717 \\
\hline Magnesium (mg) & $182(150,223)$ & $290(233,328)$ & 0.083 \\
\hline Potassium (mg) & $677(512,870)$ & $1970(1560,2844)$ & $0.002^{*}$ \\
\hline Calcium (mg) & $137(107,202)$ & $382(287,496)$ & $0.015^{*}$ \\
\hline Iron (mg) & $12.7(10.3,15.3)$ & $13.7(10.3,16.3)$ & 0.717 \\
\hline Zinc (mg) & $8.71(6.78,10.4)$ & $7.92(4.90,9.72)$ & 0.746 \\
\hline
\end{tabular}

${ }^{1}$ Generated from Median test.

${ }^{2} \mathrm{NA}$ - Not Applicable; Prisoners and guards have different requirements based on body mass.

* Significant P-value $p<0.05$.

fat, vitamin A, riboflavin, folate, vitamin $C$, vitamin $E$, potassium and calcium. The median energy intake of the prisoners was $7430 \mathrm{~kJ}\left(\mathrm{P}_{25} 6170, \mathrm{P}_{75}\right.$ 8600) compared with an estimated requirement based on FAO calculations of $7618 \mathrm{~kJ}\left(\mathrm{P}_{25} 7952, \mathrm{P}_{75}\right.$ 8285). For the guards the estimated intake was $8360 \mathrm{~kJ}\left(\mathrm{P}_{25} 6990, \mathrm{P}_{75}\right.$ 9150) with a requirement of $8610 \mathrm{~kJ}\left(\mathrm{P}_{25} 8142, \mathrm{P}_{75} 8809\right)$ [13].

The median intakes of nutrients expressed as a proportion of the estimated average requirement (EAR) are shown in Figure 1. The median intake of the prisoners was close to or exceeded the EAR for protein, zinc, iron, vitamin $B_{12}$ and $B_{6}$, niacin and thiamin. Less than $25 \%$ of the prisoners met the EAR for vitamin A, folate, vitamin $C$, vitamin $E$, potassium and calcium assuming their intake from the 24-hour recall was representative of their usual intake. The intakes of these marginal nutrients were somewhat enhanced in the diets of seven

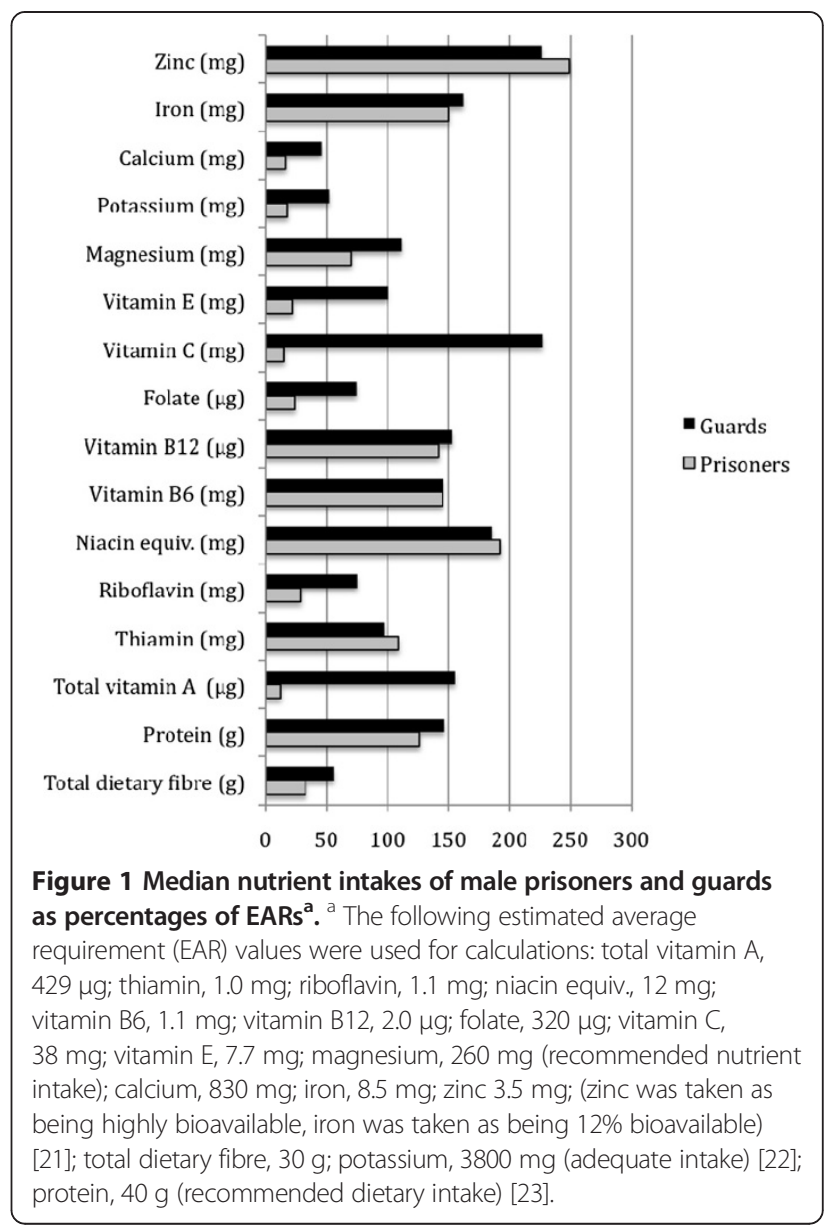

prisoners who received food regularly once a week from visitors. On average, these prisoners consumed an extra $148 \mu \mathrm{g}$ vitamin A (35\% EAR), $0.12 \mathrm{mg}$ riboflavin $(11 \%$ EAR), $31.5 \mu \mathrm{g}$ folate (10\% EAR), $18.3 \mathrm{mg}$ vitamin C (49\% EAR) and $451 \mathrm{mg}$ potassium (10\% EAR) when compared with prisoners who did not receive food gifts. As depicted in Figure 1, the guards' intake was closer to the EAR for the majority of nutrients compared with the prisoners'.

Fasting blood samples were collected from 139 prisoners and 9 guards. As shown in Table 3, over half of the prisoners had biomarker concentrations below recommended cut-offs for retinol, vitamin $\mathrm{C}$ and zinc. Nearly all prisoners had deficient plasma folate concentrations. Most had red blood cell folate concentrations indicative of depletion whilst approximately one-third were deficient. Shorterterm prisoners ( $<18$ weeks incarceration) were found to have significantly higher red blood cell folate concentrations (390 nmol/L: 95\% CI 370, 410) compared with longer-term prisoners (260 nmol/L: 95\% CI 240, 280) $(\mathrm{p}<0.001)$. Most prisoners were hyperhomocysteinemic, with approximately one-third having severe hyperhomocysteinemia $(50-500 \mu \mathrm{mol} / \mathrm{L})$. Several of the guards also 
Table 3 Median $\left(P_{25}, P_{75}\right)$ blood indices of nutrient status in male prisoners and guards (all tests undertaken with serum unless otherwise stated)

\begin{tabular}{|c|c|c|c|c|c|}
\hline & Prisoners $\left(n=139^{a}\right)$ & Guards $\left(n=9^{a}\right)$ & $P$ & Cut-off $^{b}$ & $\begin{array}{c}\text { Prisoners < or > } \\
\text { cut-off } \mathbf{n}(\%)\end{array}$ \\
\hline \multirow[t]{2}{*}{ Retinol $(\mu \mathrm{mol} / \mathrm{L})$} & $0.73(0.40,1.21)$ & $1.36(0.96,1.67)$ & 0.016 & $<1.05$ marginal & $90(65)$ \\
\hline & & & & $<0.70$ deficient & $63(46)$ \\
\hline ß-Carotene $(\mu \mathrm{mol} / \mathrm{L})$ & $<0.06(<0.06,0.09)$ & $0.25(0.15,0.36)$ & 0.000 & & \\
\hline a-Tocopherol $(\mu \mathrm{mol} / \mathrm{L})$ & $15.5(12.5,18.3)$ & $23.2(20.2,27.0)$ & 0.002 & $<11.6$ deficienct & $25(18)$ \\
\hline Cholesterol (mmol/L) & $4.4(3.8,5.1)$ & $5.5(4.6,7.0 ß)$ & 0.016 & $>5.2$ high & $27(20)^{c}$ \\
\hline $\begin{array}{l}\text { a-Tocopherol: total cholesterol ratio } \\
(\mu \mathrm{mol} / \mathrm{mmol})\end{array}$ & $3.43(2.96,3.81)$ & $3.67(4.04,5.09)$ & 0.016 & $<2.2$ inadequate & $0(0)$ \\
\hline Lutein $(\mu \mathrm{mol} / \mathrm{L})$ & $1.58(1.13,2.40)$ & $5.48(4.34,6.91)$ & 0.002 & & \\
\hline Plasma vitamin $C(\mu \mathrm{mol} / \mathrm{L})$ & $6.3(1.0,19.3)$ & $48.5(17.2,59.4)$ & 0.002 & $<11.4$ deficienct & $87(64)$ \\
\hline $\begin{array}{l}\text { Red cell thiamin pyrophosphate } \\
(\mathrm{nmol} / \mathrm{L})\end{array}$ & $258(215,307)$ & $167(133,200)$ & 0.016 & $<140$ risk of suboptimal status & $1(1)$ \\
\hline Plasma riboflavin (nmol/L) & $221(164,282)$ & $333(255,377)$ & 0.013 & $<155$ deficienct & $25(18)$ \\
\hline Plasma folate (nmol/L) & $2.0(1.35,2.6)$ & $2.8(1.6,4.0)$ & 0.246 & $<6.8$ negative balance & $134(98)$ \\
\hline \multirow[t]{2}{*}{ Red blood cell folate (nmol/L) } & $270(180,348)$ & $380(262,492)$ & 0.0850 .168 & $<363$ depletion & $105(80)$ \\
\hline & & & & $<227$ anemia & $46(35)$ \\
\hline Vitamin $B_{12}(p m o l / L)$ & $465(382,564)$ & $340(289,440)$ & 0.016 & $<130$ risk of deficiency & $0(0)$ \\
\hline Holotranscobalamin II (pmol/L) & $76(62.5,93)$ & $64(53,82.5)$ & 0.302 & $<23$ deficienct & $0(0)$ \\
\hline \multirow[t]{3}{*}{ Plasma homocysteine $(\mu \mathrm{mol} / \mathrm{L})$} & $36(18,58)$ & $16(10,56)$ & 0.388 & $>15$ moderate hhcy & $108(79)^{c}$ \\
\hline & & & & $>25$ intermediate & $92(68)^{c}$ \\
\hline & & & & 50-500 severe & $48(35)^{c}$ \\
\hline Selenium $(\mu \mathrm{mol} / \mathrm{L})$ & $1.59(1.48,1.75)$ & $1.55(1.49,1.88)$ & 0.333 & $<1.27$ inhibited GSHPx activity & $0(0)$ \\
\hline Zinc $(\mu \mathrm{mol} / \mathrm{L})$ & $9.9(8.8,11.1)$ & $10.2(9.0,10.8)$ & 0.974 & $<10.7$ & $90(65.7)$ \\
\hline Ferritin $(\mu \mathrm{g} / \mathrm{L})$ & $73(40,120)$ & $90(77,141)$ & 0.2063 & $<15$ depleted stores & $10(7.6)$ \\
\hline a-1 acid glycoprotein (mg/dL) & $64(54,73)$ & $56(55,70)$ & 0.4885 & $>120$ subclinical infection & $1(0.76)$ \\
\hline
\end{tabular}

Not all data are complete.

${ }^{b}$ Cut-offs used to define risk of micronutrient deficiencies were obtained from the following sources: serum retinol [24]; serum vitamin C [25]; serum a-tocopherol [26]; serum a-tocopherol: total cholesterol ratio [25]; red cell thiamin [27]; serum vitamin $B_{12}$ [28]; serum holotranscobalamin II [26]; plasma FAD (Canterbury Laboratories), haematocrit [29], plasma folate [30]; plasma homocysteine [31]; serum selenium [32]; total serum cholesterol [33]; serum iron [21]; serum zinc [34]; serum a-1 acid glycoprotein [35].

${ }^{c} \mathrm{n}(\%)$ above cut-off.

* Significant P-value $p<0.05$.

had low folate and high homocysteine concentrations. Biomarkers of $\alpha$-tocopherol, thiamin, vitamin $\mathrm{B}_{12}$ and selenium were largely within the normal ranges for both prisoners and guards. The guards had a significantly lower red cell thiamin pyrophosphate concentration than the prisoners $(\mathrm{p}<0.05)$.

\section{Discussion}

Our investigation highlights the dietary deficiencies of prisoners incarcerated at Beon Prison. Xerophthalmia in the prisoners was found to be associated with a low intake of vitamin A [8] and optic neuropathy with low folate status [7]. The extremely low folate concentrations found would render the prisoners at high risk of megaloblastic anaemia [30]. Additionally, high homocysteine concentrations are associated with an increased risk of arteriosclerosis [36]. Most of the prisoners had inadequate vitamin $\mathrm{C}$ intakes and $64 \%$ had deficient plasma vitamin $\mathrm{C}$ concentrations placing them at risk of scurvy.

The guards were consuming a wider variety of foods associated with better biochemical indices for several nutrients. Our ability to compare the diets of the prisoners to that of local residents as a means of placing the prison rations in context was limited to just a few guards and in this regard, a larger sample of non-prisoners would have been beneficial. Nevertheless, the prisoners' mean intake of vitamin A, riboflavin, folate, vitamin C, vitamin $\mathrm{E}$ and potassium were significantly below that of the guards suggesting an adverse disparity in the diets of the prisoners compared with the outside population. Indeed, the guards report a regular consumption of green vegetables, fruit and nuts, food items that were rarely available to the prisoners. Both prisoners and guards had low calcium intakes, almost certainly a consequence of a 
lack of dairy products being consumed with both groups being at risk of osteomalacia. Red cell thiamin was higher in the prisoners compared with the guards, presumably as a consequence of the prisoner's rice being fortified with thiamin. The serum concentration of selenium was above cut-off concentrations below which the activity of selenium-dependent enzymes are compromised [32].

Although the dietary intakes are based only on one recall, we have some reassurance regarding the accuracy of the estimates because biomarker concentrations in the prisoners were generally congruous with the nutrient intake data. Low intakes of folate, vitamin C, and vitamin A were reflected in low blood concentrations of these micronutrients and an adequate intake of thiamin and vitamin $B_{12}$ corresponded to sufficient concentrations of thiamin, vitamin $B_{12}$ and holotranscobalamin II (a vitamin $B_{12}$ metabolite) in the blood. The estimated riboflavin intake of the prisoners of $0.3 \mathrm{mg} / \mathrm{d}$ was well below the EAR and considerably less than $0.5-0.6 \mathrm{mg} / \mathrm{d}$, the amount considered essential to avoid clinical signs of deficiency [37]. However, despite these low intakes, most prisoners had plasma riboflavin concentrations above the cut-off for deficiency of this metabolite. Given that the intake and biochemical data are incongruous, it is possible that the prison rations contained more riboflavin than indicated from the food composition tables. The estimated vitamin $E$ intake was just one-sixth of the EAR whereas the serum measures ( $\alpha$-tocopherol and the ratio of $\alpha$-tocopherol/cholesterol) were for the majority of prisoners above the cut-off values. This mismatch is not necessarily inconsistent because circulating $\alpha$-tocopherol concentrations have been found not to correlate with dietary intake of vitamin E [38]. The energy intakes of the prisoners were somewhat less than calculated requirements although the mean BMI of the prisoners was in the healthy range. The absence of beriberi in Beon Prison is almost certainly due to the fortification of white rice with thiamin. Care should be taken if the supply of rice changes from the current fortified rice to an unfortified source as this may lead to thiamin deficiency.

The provision of a nutritionally adequate diet is a basic human right [39] and acknowledgement of this right is contained in the constitutional documents of Papua New Guinea [40]. The inadequacy of the prison diet is placing the prisoners at risk of acute and chronic nutrient deficiency diseases. The prison rations are supplemented in some prisoners with food brought in by weekend visitors, but not all prisoners receive visitors and the nutrient contribution of the additional food to the composition of the overall diet is small. The prison diet is likely chosen because of ease of storage, preparation and availability of food items. However, the right to adequate food is not being met by the current prison feeding regimen. With the prior consent of the prisoners, the prison authorities were notified of those prisoners diagnosed as having xerophthalmia and advised to supply them with vitamin A supplements. More generally, recommendations have been made to the authorities to procure multivitamin and mineral supplements and in the longer term, to improve the diet quality of the prisoners by the inclusion of fruit, vegetables and milk powder. Locally available foods such as avacado, banana, papaya, green leafy vegetables including aibika and broccoli, and orange colored sweet potato (kaukau) will provide several of the deficient nutrients including folate, vitamin $\mathrm{C}$, fibre and provitamin A carotenoids. Milk powder available in local supermarkets would be a good source of calcium and the provision of three cups of milk per day, and adding milk powder to tea, would substantially improve calcium intakes. Calcium would also be provided by the consumption of small whole fish with soft bones, although the availability of this on a regular basis may be difficult.

\section{Conclusions}

The prison rations were lacking in variety resulting in an inadequate intake of several essential nutrients to prisoners. Testing of blood samples confirmed that dietary inadequacy was reflected in biochemical indicators. From a clinical eye examination, the nutrition related diseases xerophthalmia and optic neuropathy were identified. Elsewhere, severe malnutrition has been documented in prisoners in Zimbabwe [41], Democratic Republic of Congo, as well as vitamin A deficiency in Kenya [2] and beriberi in the Cote d'Ivoire $[3,42]$. Clearly, ongoing vigilance of prisoners' diets is required.

\section{Competing interests}

The authors declared that they have no competing interest.

\section{Authors' contributions}

$C G, B V, R G, B T$ and $G B$ designed the study. CG, BV, BT and RM conducted the on-site investigation. CG and KB conducted the laboratory blood analysis. CG analysed the dietary data. Statistical analysis was undertaken by CG and BV, and data interpretation by $C G, B V, R G, B T$ and $G B$. The initial draft manuscript was prepared by CG, BV, RG, BT and GB with all authors involved in editing subsequent drafts. All authors read and approved the final manuscript.

\section{Acknowledgements}

The authors thank Dr. Clement Manineng, Dr. Vincent Atua, Jade Marshall, and eye unit nurses (Modilon General Hospital) and student rural health officers (Divine Word University) who participated in data collection; and, the Papua New Guinea Institute for Medical Research for assistance in storage and shipment of the blood samples. The authors acknowledge Dr. Stephen Demok, whose clinical observations gave rise to this investigation; and, for their cooperation, the authorities at Beon Prison, the Department of Correctional Services, and the National Department of Health. The authors also thank Ashley Duncan, Michelle Harper and Holiday Wilson in the research laboratories at the University of Otago for their technical support and laboratory biochemical analysis.

\section{Funding}

The design, implementation and analysis of this study were financially supported by the New Zealand Agency for International Development (NZAID) through the Kaihono hei Oranga Hapori o te Ao Partnerships for International Community Development scheme (KOHA-PICD), the Department of Human Nutrition of the University of Otago, and The Fred Hollows Foundation New Zealand. 


\section{Author details}

'Department of Human Nutrition, University of Otago, P.O. Box 56, Dunedin 9054, New Zealand. ${ }^{2}$ The Fred Hollows Foundation New Zealand, Private Bag 99909, Newmarket, Auckland 1149, New Zealand. ${ }^{3}$ Faculty of Health Sciences, Divine Word University, Madang, Papua New Guinea, 1 Nabasa Road, Madang, Madang Province 511, Papua New Guinea. ${ }^{4}$ Dunedin School of Medicine, University of Otago, P.O. Box 913, Dunedin 9054, New Zealand.

Received: 29 October 2012 Accepted: 9 April 2013

Published: 22 April 2013

\section{References}

1. Bennett M, Coninx R: The mystery of the wooden leg: vitamin C deficiency in East African prisons. Trop Doct 2005, 35:81-84.

2. Mathenge $W$, Kuper $H$, Myatt M, Foster A, Gilbert C: Vitamin A deficiency in a Kenyan prison. Trop Med Int Health 2007, 12:269-273.

3. Ahoua L, Etienne W, Fermon F, Godain G, Brown V, Kadjo K, Bouaffou K, Legros D, Guerin P: Outbreak of beriberi in a prison in Côte d'Ivoire. Food Nutr Bull 2007, 28:283-990.

4. Demok S: Preliminary report on ocular survey of long term prisoners at Beon correctional institution services. 2007. Unpublished, personal communication.

5. The Cuba Field Investigation Team: Epidemic optic neuropathy in Cubaclinical characterization and risk factors. N Eng J Med 1995, 333:1176-1182.

6. Hodson KE, Bowman RJ, Mafwiri M, Wood M, Mhoro V, Cox SE: Low folate status and indoor pollution are risk factors for endemic optic neuropathy in Tanzania. Br J Ophthalmol 2011, 95:1361-1364.

7. Tousignant B, Brian G, Venn B, Gould C, McKay R, Williams S: Optic neuropathy among a prison population in Papua New Guinea. Ophthalmic Epidemiol 2012. In press.

8. Brian G, Tousignant B, Venn BJ, McKay R, Gould C: Serum retinol and xerophthalmia among a prison population in Papua New Guinea. Ophthalmic Epidemiol 2011, 18:288-294.

9. Gibson RS, Ferguson EL: An interactive 24-hour recall for assessing the adequacy of iron and zinc intakes in developing countries. HarvestPlus Technical Monograph 8. Washington D.C. and Cali: International Food Policy Research Institute (IFPRI) and International Center for Tropical Agriculture (CIAT); 1999.

10. Dignan CA, Burlingame BA, Kumar S, Aalbersberg W: The Pacific Islands food composition tables. 2nd edition. Rome: Food and Agricultural Organization; 2004.

11. Food Standards Australia New Zealand: NUTTAB2010 nutrient data table for use in Australia. 2010. Internet http://www.foodstandards.govt.nz/ accessed August.

12. Lesperance L: The Concise New Zealand Food Composition Tables. 8th edition. Palmerston North: New Zealand Institute for Plant and Food Research; Ministry of Health; 2009.

13. Food and Agriculture Organization, World Health Organization, United Nations University: Human energy requirements: a report of a joint FAONHO/ UNU expert consultation. Rome: FAO Food and Nutrition Technical Report Series; 2001.

14. Thurnham D, Smith E, Flora P: Concurrent liquid-chromatographic assay of retinol, alpha-tocopherol, beta-carotene, alpha-carotene, lycopene and beta-cryptoxanthinin plasma with tocopherol acetate as internal standard. Clin Chem 1988, 34:377-381.

15. O'Broin S, Kelleher B: Microbiological assay on microtitre plates of folate in serum and red cells. J Clin Pathol 1992, 45:344-347.

16. Vuilleumier J, Keck E: Fluorometric assay of vitamin $\mathrm{C}$ in biological materials using a centrifugal analyser with fluorescence attachment. J Micronutrient Anal 1989, 5:25-34.

17. Jacobson BE, Lockitch $\mathrm{G}$ : Direct determination of selenium in serum by graphite-furnace atomic absorption spectrometry with deuterium background correction and a reduced palladium modifier: age-specific reference ranges. Clin Chem 1988, 34:709-714.

18. Ubbink J, Hayward Vermaak W, Bissbort S: Rapid high-performance liquid chromatographic assay for total homocysteine levels in human serum. J Chromatogr 1991, 565:441-446.

19. Smith JC, Butrimovitz GP, Purdy WC: Direct measurement of zinc in blood plasma by atomic absorption spectrometry. Clin Chem 1979, 25:1487-1491.

20. World Health Organization: Obesity: preventing and managing the global epidemic. Report of a WHO Consultation. World Health Organ Tech Rep Ser 2000, 894:i-xii. 1-253.
21. Food and Agriculture Organization of the United Nations / World Health Organization: Report of a joint FAOWHO expert consultation Bangkok, Thailand. Rome: Food and Nutrition Division FAO; 2001

22. National Health and Medical Research Council: Nutrient reference values for Australia and New Zealand. Canberra, Australia: NHMRC publications; 2006.

23. Food and Agriculture Organization, World Health Organization, United Nations University: Protein and amino acid requirements in human nutrition: a report of a joint FAO/WHO/UNU expert consultation. Geneva: WHO Technical Report Series no. 935; 2002.

24. de Pee S, Dary O: Biochemical indicators of vitamin A deficiency: serum retinol and serum retinol binding protein. J Nutr 2002, 132:2895S-2901S

25. Gibson R: Principles of Nutritional Assessment. 2nd edition. Oxford University Press; 2005.

26. Sauberlich H: Laboratory Tests for the Assessment of Nutritional Status. Boca Raton, Florida: CRC Press LLC; 1999.

27. Wilkinson T, Hanger H, Elmslie J, George P, Sainsbury R: The response to treatment of subclinical thiamine deficiency in the elderly. Am J Clin Nutr 1997, 66:925-928.

28. Food and Agriculture Organization, World Health Organization: FAO, Rome: Requirements of Vitamin A, Iron, Folate and Vitamin B12. FAO/WHO Expert Consultation. Food and Nutrition Series No. 23; 1988

29. Stoltzfus R, Dreyfuss M: Guidelines for the Use of Iron Supplements to Prevent and Treat Iron Deficiency Anemia: International Nutritional Anemia Consultative Group (INACG), World Health Organization (WHO), United Nations Children's Fund (UNICEF). Washington: International Life Sciences Institute; 1998.

30. Herbert V: Biochemical and hematological lesions in folic acid deficiency. Am J Clin Nutr 1967, 20:562-569.

31. Jacobsen D: Homocysteine and vitamins in cardiovascular disease. Clin Chem 1998, 44:1833-1843.

32. Thomson CD: Assessment of requirements for selenium and adequacy of selenium status: a review. Eur J Clin Nutr 2004, 58:391-402

33. Roth GA, Fihn SD, Mokdad AH, Aekplakorn W, Hasegawa T, Lim SS: High total serum cholesterol, medication coverage and therapeutic control: an analysis of national health examination survey data from eight countries. Bull World Health Organ 2011, 89:92-101.

34. Brown KH, Rivera JA, Bhutta Z, Gibson RS, King JC, Lonnerdal B, Ruel MT, Sandtrom B, Wasantwisut E, Hotz C: International Zinc Nutrition Consultative Group (IZiNCG) technical document \#1. Assessment of the risk of zinc deficiency in populations and options for its control. Food Nutr Bull 2004, 25:S99-S203.

35. Hochepied T, Berger FG, Baumann H, Libert C: Alpha(1)-acid glycoprotein an acute phase protein with inflammatory and immunomodulating properties. Cytokine Growth Factor Rev 2003, 14:25-34.

36. Ciaccio M, Bellia C: Hyperhomocysteinemia and cardiovascular risk: effect of vitamin supplementation in risk reduction. Curr Clin Pharmacol 2010, 5:30-36

37. Institute of Medicine: Dietary Reference Intakes for Thiamin, Riboflavin, Niacin, Vitamin B6, Folate, Vitamin B12, Pantothenic Acid, Biotin, and Choline. Washington, D.C: National Academy Press; 1998.

38. Kardinaal AF, van 't Veer P, Brants HA, van den Berg H, van Schoonhoven J, Hermus RJ: Relations between antioxidant vitamins in adipose tissue, plasma, and diet. Am J Epidemiol 1995, 141:440-450.

39. United Nations: The universal declaration of human rights. Article 25. Internet http://www.un.org/en/documents/udhr/ accessed 23rd October 2012

40. Knuth L, Vidar M: Constitutional and legal protection of the right to food around the world. Rome: Food and Agriculture Organization of the United Nations; 2011

41. Alexander J: Death and disease in Zimbabwe's prisons. Lancet 2009, 373:995-996.

42. Aké-Tano O, Konan E, Tetchi E, Ekou F, Ekra D, Coulibaly A, Dagnan N: Beriberi, recurrent nutritional disease in a detention house in Côted'Ivoire. Bull Soc Pathol Exot 2010, 104:347-351.

doi:10.1186/1472-698X-13-21

Cite this article as: Gould et al:: Cross-sectional dietary deficiencies among a prison population in Papua New Guinea. BMC International Health and Human Rights 2013 13:21. 